\title{
EFISIENSI PEMUPUKAN UREA DAN LAHAN PADA TUMPANGSARI JAGUNG DAN KACANG TANAH DALAM MENINGKATKAN HASIL JAGUNG
}

\author{
Tyas Hendra Sonjaya, Herawati Hamim \& Niar Nurmauli \\ Jurusan Agroteknologi, Fakultas Pertanian Universitas Lampung \\ Jl. Prof. Soemantri Brodjonegoro, No. 1 Bandar Lampung 35145 \\ E-mail: styashendra@yahoo.com
}

\begin{abstract}
ABSTRAK
Penanaman jagung dengan kacang tanah dapat menjadi pilihan yang ideal dalam penerapan pola tanam tumpangsari. Nitrogen yang berasal dari tanaman kacang tanah dapat membantu pemenuhan kebutuhan $\mathrm{N}$ tanaman jagung. Penelitian bertujuan untuk mengetahui efisiensi pemupukan urea dan penggunaan lahan pada pola tanam tumpangsari jagung dan kacang tanah dalam meningkatkan hasil jagung. Rancangan yang digunakan adalah rancangan kelompok teracak sempurna (RKTS) dengan sembilan perlakuan yang diulang tiga kali, yaitu tumpangsari jagung dan kacang tanah dengan tujuh taraf dosis pupuk masing-masing 0, 50, 100, 150, 200, 250, dan $300 \mathrm{~kg}$ urea/ha, monokultur kacang tanah, dan monokultur jagung. Pengelompokan didasarkan pada waktu pengamatan. Homogenitas ragam diuji dengan uji Barlett, kemenambahan data diuji dengan uji Tukey, dan untuk pemisahan nilai tengah dilakukan uji perbandingan ortogonal pada taraf nyata $5 \%$. Hasil penelitian menunjukkan bahwa laju tumbuh tanaman, laju pengisian biji, bobot pipilan kering, dan indeks panen jagung pada pola tanam monokultur lebih baik dibanding pada pola tanam tumpangsari. Penerapan tumpangsari jagung dan kacang tanah tidak menunjukkan efisiensi pemupukan urea secara agronomis karena peningkatan bobot pipilan kering jagung hanya sebesar $0,004 \mathrm{t} / \mathrm{ha}(4 \mathrm{~kg} /$ ha) setiap peningkatan dosis $1 \mathrm{~kg}$ urea/ha, namun pada lahan tumpangsari jagung dan kacang tanah dengan dosis 200, 250, dan $300 \mathrm{~kg}$ urea/ha menunjukkan efisiensi penggunaan lahan dengan nilai LER masing-masing 1,18, 1,19, dan 1,30.
\end{abstract}

Kata kunci: Jagung, kacang tanah, LER, tumpangsari, urea

\section{PENDAHULUAN}

Salah satu upaya untuk meningkatkan produksi jagung adalah intensifikasi pertanian dengan penerapan pola tanam tumpangsari. Tumpangsari dapat didefinisikan sebagai suatu cara bercocoktanam pada sebidang lahan dimana dua atau lebih spesies tanaman ditanam dan tumbuh bersama dalam jarak dan larikan yang teratur (Nurmas, 2011). Menurut Pasau, dkk.(2008), tujuan penerapan pola tanam tumpangsari adalah penggunaan lahan seefektif mungkin, khususnya di daerah dengan lahan usaha terbatas. Selain itu, penerapan pola tanam tumpangsari bertujuan untuk memanfaatkan faktor produksi lain seperti tenaga kerja dan modal kerja secara optimal, pemakaian pupuk dan pestisida lebih efisien, mengurangi erosi, konservasi lahan, stabilitas biologi tanah, dan mendapatkan produksi total yang lebih besar dibandingkan pada pola tanam monokultur (Tharir dan Hadmadi, 1984 dalam Prasetyo, dkk., 2009). Sabaruddin dkk (2003) menambahkan, pada pola tanam tumpangsari penyediaan nitrogen meningkat bila menggunakan tanaman kacang-kacangan. Penanaman jagung dengan kacang tanah dapat menjadi pilihan yang ideal dalam penerapan pola tanam tumpangsari.

Kacang tanah merupakan tanaman legum yang mampu mengikat $\mathrm{N}$ bebas dari udara karena bersimbiosis dengan bakteri Rhizobium. Simbiosis yang terjadi dalam keadaan lingkungan yang memenuhi persyaratan tumbuh mampu memenuhi sebagian atau bahkan seluruh kebutuhan N bagi tanaman (Saono, 1981 dalam Purwaningsih, 2009). Pilbeam, dkk. (1995) menjelaskan, bila tanaman kacang-kacangan ditanam dengan tanaman serealia, $\mathrm{N}$ dari tanaman yang diasosiasikan akan meningkat, salah satunya dengan transfer langsung $\mathrm{N}$ dari tanaman kacang-kacangan ke tanaman serealia atau oleh penguraian secara sederhana mineral yang tersedia di dalam tanah.

Nitrogen yang berasal dari tanaman kacang tanah dapat membantu pemenuhan kebutuhan $\mathrm{N}$ tanaman jagung. Ahmad, dkk. (2008) menjelaskan, kontribusi N dari kacang tanah pada pertumbuhan jagung dalam pola tanam tumpangsari adalah sama dengan aplikasi $96 \mathrm{~kg}$ pupuk $\mathrm{N}$ per hektar pada rasio kepadatan populasi tanaman satu tanaman jagung berbanding empat 
tanaman kacang tanah. Dengan demikian, penggunaan pupuk urea untuk tanaman jagung pada tumpangsari dengan kacang tanah perlu dikaji lebih lanjut. Penelitian bertujuan untuk mengetahui efisiensi pemupukan urea dan penggunaan lahan pada pola tanam tumpangsari jagung dan kacang tanah dalam meningkatkan hasil jagung.

\section{BAHAN DAN METODE}

Penelitian dilaksanakan di Laboratorium Lapang Terpadu dan Laboratorium Tanaman Fakultas Pertanian Universitas Lampung pada bulan Agustus - Desember 2014. Bahan yang digunakan adalah benih jagung hibrida NK 22, benih kacang tanah varietas Kelinci, pupuk urea, pupuk TSP, pupuk $\mathrm{KCl}$, insektisida Dharmafur 3GR, Rudal 25 EC, fungisida Antracol 70 WP, dan air. Alat-alat yang digunakan adalah cangkul, tali rafia, alat tugal, koret, selang, tank sprayer, meteran, gunting, timbangan digital, dan oven.

Rancangan yang digunakan adalah rancangan kelompok teracak sempurna (RKTS) dengan sembilan perlakuan yang diulang tiga kali, yaitu tumpangsari jagung dan kacang tanah dengan tujuh taraf dosis pupuk masing-masing $0,50,100,150,200,250$, dan $300 \mathrm{~kg}$ urea/ha, monokultur kacang tanah, dan monokultur jagung. Pengelompokan didasarkan pada waktu pengamatan. Homogenitas ragam diuji dengan uji Barlett, kemenambahan data diuji dengan uji Tukey, dan untuk pemisahan nilai tengah dilakukan uji perbandingan ortogonal pada taraf nyata $5 \%$.

Tanah diolah dua kali dengan menggunakan cangkul, setelah itu dibuat petak percobaan dengan ukuran 3 x 3 m sebanyak 27 petak. Jarak antarpetak $0,5 \mathrm{~m}$ dan jarak antarkelompok $1 \mathrm{~m}$. Penanaman jagung dan kacang tanah dilakukan bersamaan. Benih jagung dan kacang tanah ditanam secara tugal sedalam kirakira $3 \mathrm{~cm}$ sebanyak 1 benih per lubang tanam. Saat benih jagung dan kacang tanah ditanam, setiap lubang tanam diberi Dharmafur 3GR. Penyulaman dilakukan pada umur 10 hari setelah tanam (HST). Pupuk urea diberikan dua kali, yaitu setengah diberikan pada saat tanaman berumur 8 hari dan setengah dosis diberikan saat tanaman berumur 22 hari dengan tujuan semua tanaman telah tumbuh $100 \%$ dan memenuhi jumlah populasi tanaman per petak perlakuan. Pupuk SP-36 dan $\mathrm{KCl}$ diberikan sekaligus bersamaan dengan pemberian pupuk urea pertama. Dosis pupuk urea untuk jagung sesuai dengan perlakuan, sedangkan dosis pupuk lainnya $150 \mathrm{~kg} \mathrm{SP-36/ha} \mathrm{dan} 100 \mathrm{~kg} \mathrm{KCl} / \mathrm{ha}$. Pada kacang tanah dosis pupuk $100 \mathrm{~kg}$ urea/ha, $100 \mathrm{~kg}$ SP36/ha, dan $100 \mathrm{~kg} \mathrm{KCl} / \mathrm{ha}$, pupuk diberikan dengan cara larikan dalam baris. Pemeliharaan tanaman yang dilakukan adalah penyiraman, penyiangan, dan pengendalian hama dan penyakit. Penyiraman dilakukan setiap saat tanah dianggap kurang air untuk tanaman jagung dan kacang tanah. Penyiangan dilakukan pada umur $21 \mathrm{HST}$. Pengendalian hama dan penyakit dilakukan penyemprotan Rudal 25 EC dan Antracol 70 WP apabila timbul gejala serangan.

Panen pada kacang tanah dilakukan setelah menunjukkan ciri-ciri: sebagian besar polongnya (80\%) telah tua, kulit polong cukup keras dengan guratan yang jelas, kulit biji tipis dan mengkilap, rongga polong telah berisi penuh dengan biji, dan terdapat bercak hitam pada kulit bagian dalam. Panen pada jagung dilakukan apabila $75 \%$ dari populasi telah menunjukkan ciri-ciri daun telah menguning bahkan sebagian besar mulai kering, kelobot sudah kering atau kuning, apabila kelobot di buka, maka terlihat biji mengkilap dan keras, apabila digores dengan kuku tidak akan membekas pada biji (Buhaira, 2007).

Peubah yang diamati terdiri dari laju tumbuh tanaman, laju pengisian biji, bobot pipilan kering jagung, indeks panen, efisiensi pemupukan urea secara agronomis, efisiensi penggunaan lahan, dan didukung data analisis tanah dan curah hujan.

\section{HASIL DAN PEMBAHASAN}

Hasil penelitian menunjukkan bahwa laju tumbuh tanaman, laju pengisian biji, bobot pipilan kering, dan indeks panen jagung pada pola tanam monokultur lebih tinggi daripada pola tanam tumpangsari (Tabel 1). Beberapa peubah pengamatan menunjukkan hasil jagung yang lebih tinggi pada pola tanam monokultur diduga karena tidak adanya persaingan seperti persaingan antara tanaman jagung dengan kacang tanah pada pola tanam tumpangsari. Arma, dkk. (2013) menjelaskan, penanaman kacang tanah bersamaan jagung dapat menimbulkan persaingan yang sangat tinggi karena memiliki kebutuhan unsur hara, air, dan cahaya matahari yang sama yang akan digunakan dalam proses fotosintesis.

Pada dasarnya baik pada pola tanam monokultur maupun pada pola tanam tumpangsari tanaman jagung sama-sama tidak mendapatkan cukup air karena data curah hujan menunjukkan mulai dari penanaman sampai panen tidak terdapat cukup air (Tabel 5). Hal ini menyebabkan pupuk yang diberikan tidak dapat dimanfaatkan secara maksimal mengingat dalam upaya pemanfaatannya nitrogen harus berinteraksi dengan air sebelum akhirnya bisa sampai ke tanaman. Data hasil analisis tanah menunjukkan bahwa nitrogen setelah penelitian pada seluruh perlakuan tumpangsari sama 
Tabel 1. Pengaruh tumpangsari jagung dan kacang tanah terhadap peubah pengamatan

\begin{tabular}{|c|c|c|c|c|c|c|c|c|c|c|}
\hline \multirow[t]{2}{*}{ Perbandingan } & \multicolumn{2}{|c|}{ LTT } & \multicolumn{2}{|c|}{ LPB } & \multicolumn{2}{|c|}{ HSL } & \multicolumn{2}{|c|}{ IP } & \multirow{2}{*}{$\begin{array}{c}\text { Ef.urea } \\
\text { Sig. }\end{array}$} & \multirow{2}{*}{$\begin{array}{c}\text { LER } \\
\text { Sig. }\end{array}$} \\
\hline & Selisih & Sig. & Selisih & Sig. & Selisih & Sig. & Selisih & Sig. & & \\
\hline Mono vs Ts & $-56,64$ & $\begin{array}{c}4,89 \\
*\end{array}$ & $-6,40$ & $\begin{array}{c}132,39 \\
*\end{array}$ & $-20,05$ & $\begin{array}{c}132,39 \\
*\end{array}$ & $-2,04$ & $\begin{array}{c}9,08 \\
*\end{array}$ & & \\
\hline P-Linier & & $\begin{array}{c}130,30 \\
*\end{array}$ & & $\begin{array}{c}156,59 \\
*\end{array}$ & & $\begin{array}{c}156,59 \\
*\end{array}$ & & $\begin{array}{c}1,69 \\
\text { th }\end{array}$ & $\begin{array}{c}1,03 \\
\text { tn }\end{array}$ & $\begin{array}{c}113,4802 \\
*\end{array}$ \\
\hline P-Kuadratik & & $\begin{array}{c}1,20 \\
\text { tn }\end{array}$ & & $\begin{array}{c}0,12 \\
\text { tn }\end{array}$ & & $\begin{array}{c}0,12 \\
\text { tn }\end{array}$ & & $\begin{array}{c}1,42 \\
\text { tn }\end{array}$ & $\begin{array}{c}0,03 \\
\text { th }\end{array}$ & $\begin{array}{c}0,0003 \\
\text { tn }\end{array}$ \\
\hline
\end{tabular}

Keterangan: $\mathrm{LTT}=$ Laju tumbuh tanaman; $\mathrm{LPB}=$ Laju pengisian biji $\mathrm{HSL}=$ Bobot pipilan kering; IP = Indeks panen; Ef.urea = Efisiensi pemupukan urea secara agronomis; LER $=$ Land Equivalence Ratio (nisbah kesetaraan lahan)

Tabel 2. Data hasil analisis tanah sebelum penelitian

\begin{tabular}{ccc}
\hline Kode Sampel & Nilai & Kriteria \\
\hline pH $\mathrm{H}_{2} \mathrm{O}$ & 6,47 & Agak Masam \\
Nitrogen $(\%)$ & 0,13 & Rendah \\
P tersedia $(\mathrm{ppm})$ & 7,95 & Sedang \\
$\mathrm{K} \mathrm{dd}(\mathrm{ml} / 100$ gram) & 0,31 & Rendah \\
\hline
\end{tabular}

*Sumber: Hardjowigeno (1987)

sebesar $0,17 \%$. Hal ini menunjukkan bahwa pemupukan urea tidak begitu berperan dalam upaya peningkatan hasil jagung, namun data hasil analisis tanah menunjukkan bahwa pada lahan dengan perlakuan monokultur kandungan nitrogen sebelum penelitian adalah sebesar $0,13 \%$, sama dengan kandungan nitrogen setelah penelitian sebesar $0,13 \%$ (Tabel 2 dan 3). Hal tersebut membantu tanaman pada lahan dengan perlakuan monokultur untuk lebih memaksimalkan laju tumbuh tanaman dan pengisian biji. Hikmawati (2015) menjelaskan, pemberian nitrogen menyebabkan tanaman banyak mengandung butir hijau daun yang mempunyai peranan sangat penting dalam proses fotosintesis dan mempercepat pertunbuhan tanaman. Ezward (2010) menambahkan, unsur hara membantu proses fisiologis tanaman berlangsung optimal, termasuk pengisian biji sampai masak fisiologi yang selanjutnya mampu meningkatkan hasil.

Bobot pipilan kering dan indeks panen jagung selanjutnya mengikuti laju tumbuh tanaman dan pengisian biji jagung yang secara nyata lebih baik pada pola tanam monokultur dibanding pada pola tanam tumpangsari. Hal ini sesuai dengan Bustamam (2004), hasil benih jagung per hektar akan ditentukan oleh bobot biji yang berkaitan erat dengan efektif atau tidaknya pengisian biji serta jumlah biji per satuan luas. Sutoro, dkk. (2008) menjelaskan, laju pengisian biji yang tinggi dan berlangsung relatif lama akan menghasilkan bobot biji yang tinggi selama biji dapat menampung hasil asimilat. Hasil penelitian Nurmas (2011) juga menunjukkan bahwa hasil tanaman jagung yang ditanam dengan pola tanam monokultur (3,5 t/ha) lebih tinggi daripada hasil tanaman jagung yang ditanam dengan pola tanam tumpangsari dengan kacang tanah baik dengan waktu penanaman jagung bersamaan dengan kacang tanah sebesar 2,6 t/ ha maupun penundaan saat tanam jagung satu minggu sebesar 2,5 t/ha dan dua minggu sebesar 2,1 t/ha.

Seperti halnya bobot pipilan kering jagung, indeks panen jagung pun lebih tinggi pada pola tanam monokultur dibanding pada pola tanam tumpangsari. Hal ini sesuai dengan pendapat Rahni (2012), ada hubungan antara indeks panen dengan hasil. Semakin tinggi nilai indeks panen berarti semakin besar hasil biji yang dihasilkan, begitupun sebaliknya. Yuliana, Sumarni, dan Fajriani (2013) menjelaskan, indeks panen menggambarkan proporsi fotosintat yang ditranslokasikan ke dalam bagian penyimpanan cadangan makan. Fotosintat tanaman jagung yang dihasilkan daun ditranslokasikan ke bagian cadangan makanan dalam bentuk biji.

Pengamatan laju tumbuh tanaman, laju pengisian biji, dan bobot pipilan kering jagung terhadap dosis pupuk untuk jagung menunjukkan respons linier. Setiap peningkatan dosis $1 \mathrm{~kg}$ urea/ha akan meningkatkan laju tumbuh tanaman jagung sebesar $0,049 \mathrm{~g} /$ tanaman, laju pengisian biji jagung sebesar $0,004 \mathrm{~g} / \mathrm{hari}$, dan bobot pipilan kering jagung sebesar 0,004 t/ha (4 kg/ha) (Gambar 1). Peningkatan hasil jagung pada tumpangsari jagung dan kacang tanah diduga karena adanya peranan dari bakteri Rhizobium. Kacang tanah merupakan tanaman legum yang mampu mengikat $\mathrm{N}$ bebas dari udara karena bersimbiosis dengan bakteri Rhizobium. Simbiosis yang terjadi dalam keadaan lingkungan yang memenuhi persyaratan tumbuh mampu memenuhi 
Tabel 3. Data hasil analisis tanah untuk nitrogen setelah penelitian

\begin{tabular}{lcc}
\hline \multicolumn{1}{c}{ Perlakuan } & Nitrogen (\%) & Kriteria* \\
\hline Monokultur jagung & 0,13 & Rendah \\
Monokultur kacang tanah & 0,18 & Rendah \\
Tumpangsari jagung \& kacang tanah; Dosis pupuk 0 kg urea/ha & 0,17 & Rendah \\
Tumpangsari jagung \& kacang tanah; Dosis pupuk $50 \mathrm{~kg}$ urea/ha & 0,17 & Rendah \\
Tumpangsari jagung \& kacang tanah; Dosis pupuk $100 \mathrm{~kg}$ urea/ha & 0,17 & Rendah \\
Tumpangsari jagung \& kacang tanah; Dosis pupuk $150 \mathrm{~kg}$ urea/ha & 0,17 & Rendah \\
Tumpangsari jagung \& kacang tanah; Dosis pupuk 200 kg urea/ha & 0,17 & Rendah \\
Tumpangsari jagung \& kacang tanah; Dosis pupuk 250 kg urea/ha & 0,17 & Rendah \\
Tumpangsari jagung \& kacang tanah; Dosis pupuk 300 kg urea/ha & 0,17 & Rendah
\end{tabular}

*Sumber: Hardjowigeno (1987)
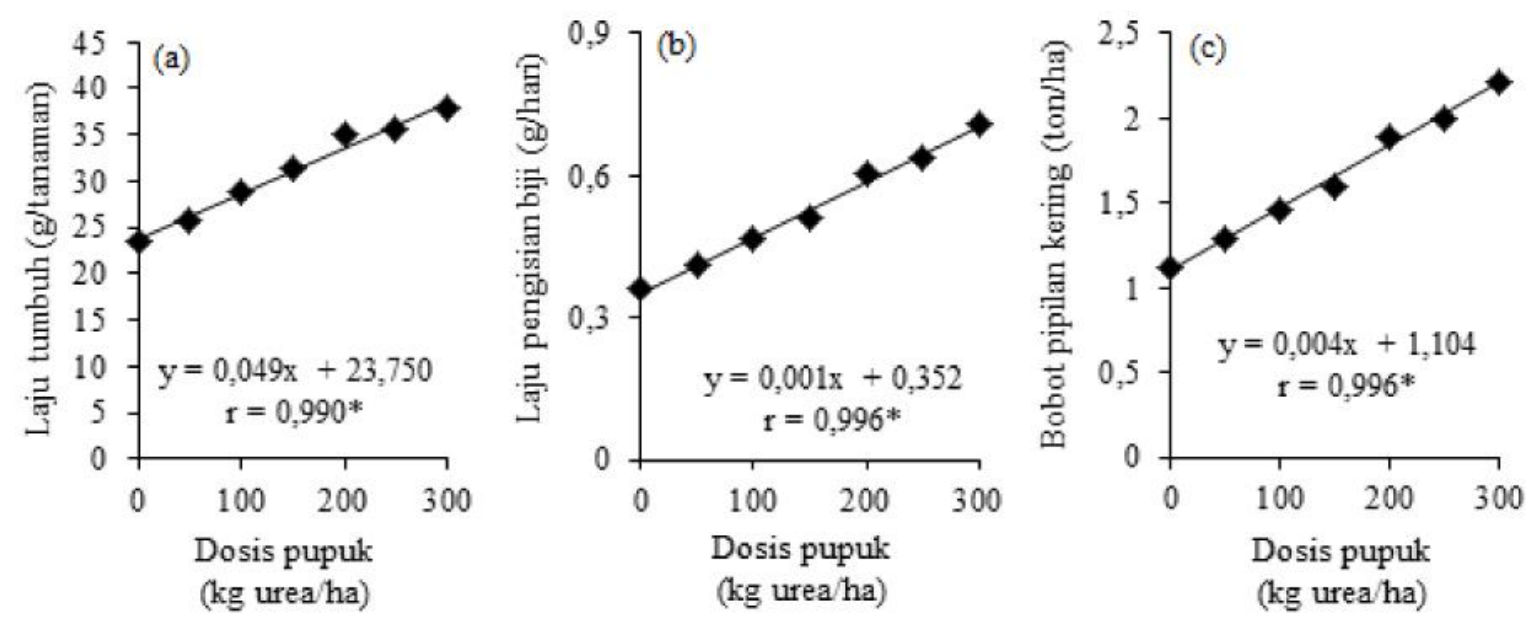

Gambar 1. Pengaruh dosis urea terhadap : (a) laju tumbuh, (b) laju pengisian biji, dan (c) bobot pipilan kering pada tanaman jagung

sebagian atau bahkan seluruh kebutuhan $\mathrm{N}$ bagi tanaman (Saono, 1981 dalam Purwaningsih, 2009).

Hasil penelitian selanjutnya menunjukkan bahwa perlakuan tidak berpengaruh terhadap efisiensi pemupukan urea secara agronomis. Menurut Drechsel dkk (2014) efisiensi agronomis yang optimal adalah dengan peningkatan hasil pipil antara 15 dan $30 \mathrm{~kg}$ per $\mathrm{kg} \mathrm{N}$ pupuk, sedangkan pada penelitian ini peningkatan bobot pipilan kering jagung hanya $1,84 \mathrm{~kg} / \mathrm{ha}$ setiap $1 \mathrm{~kg}$ $\mathrm{N} / \mathrm{ha}$ atau $4 \mathrm{~kg} / \mathrm{ha}$ setiap $1 \mathrm{~kg}$ urea/ha $(\mathrm{N}$ dalam urea 46\%). Hal tersebut menyebabkan pada pemberian pupuk sampai $300 \mathrm{~kg}$ urea/ha belum didapat dosis yang optimum. Siregar dan Marzuki (2011) menjelaskan, untuk meningkatkan efisiensi agronomis perlu dilakukan perbaikan pengelolaan tanaman dan menyesuaikan takaran pupuk dengan tabel anjuran pada target hasil. Pada dasarnya pengelolaan tanaman sudah diupayakan dengan baik dan takaran pupuk sudah disesuaikan dengan target hasil, tetapi evaporasi yang tinggi dan curah hujan yang rendah selama penelitian (Tabel 4) menyebabkan penyiraman tidak optimal dan tanaman kekurangan air. Hal ini juga yang diduga menyebabkan bobot pipilan kering jagung baik pada pola tanam monokultur sebesar 2,61 t/ha maupun tumpangsari sebesar 2,22 t/ha (dengan dosis $300 \mathrm{~kg}$ urea/ha untuk jagung) menunjukkan hasil yang jauh lebih rendah daripada potensi bobot pipilan kering jagung hibrida NK 22 yaitu 10,48 t/ha. Rahim, Rogi, dan Runtunuwu (2015) menjelaskan, untuk mendapatkan hasil jagung yang baik distribusi curah hujan harus merata selama pertumbuhan tanaman yaitu sekitar $200 \mathrm{~mm}$ per bulan dan suplai air harus cukup terutama pada fase pembungaan sampai pengisian biji.

Evaluasi keuntungan atau kerugian dari penggunaan lahan pada pola tanam tumpangsari dilakukan dengan mengetahui nilai LER. Hasil penelitian menunjukkan bahwa pada lahan tumpangsari jagung dan kacang tanah dengan dosis 200, 250, dan $300 \mathrm{~kg}$ urea/ ha untuk jagung menguntungkan dengan nilai LER masing-masing 1,$18 ; 1,19$; dan 1,30 . Hal tersebut berarti 
Tabel 4. Data evaporasi dan curah hujan

\begin{tabular}{|c|c|c|c|c|c|c|c|c|c|c|}
\hline \multirow{3}{*}{ Tgl } & \multicolumn{10}{|c|}{ Bulan } \\
\hline & \multicolumn{2}{|c|}{ Agust } & \multicolumn{2}{|c|}{ Sept } & \multicolumn{2}{|c|}{ Okt } & \multicolumn{2}{|c|}{ Nov } & \multicolumn{2}{|c|}{ Des } \\
\hline & $\underset{(\mathrm{mm} / \mathrm{hr})}{\operatorname{Evp}}$ & $\underset{(\mathrm{mm} / \mathrm{hr})}{\mathrm{CH}}$ & $\underset{(\mathrm{mm} / \mathrm{hr})}{\operatorname{Evp}}$ & $\underset{(\mathrm{mm} / \mathrm{hr})}{\mathrm{CH}}$ & $\begin{array}{c}\text { Evp } \\
(\mathrm{mm} / \mathrm{hr})\end{array}$ & $\underset{(\mathrm{mm} / \mathrm{hr})}{\mathrm{CH}}$ & $\underset{(\mathrm{mm} / \mathrm{hr})}{\operatorname{Evp}}$ & $\begin{array}{c}\mathrm{CH} \\
(\mathrm{mm} / \mathrm{hr})\end{array}$ & $\underset{(\mathrm{mm} / \mathrm{hr})}{\operatorname{Evp}}$ & $\underset{(\mathrm{mm} / \mathrm{hr})}{\mathrm{CH}}$ \\
\hline 1 & 6,8 & 0 & 4,9 & 0 & 6,9 & 0 & 6,5 & 0 & 2,7 & 10,4 \\
\hline 2 & 6,9 & 0 & 6,3 & 0 & 5,7 & 0 & 7,2 & 0 & 2,7 & 0 \\
\hline 3 & 4,8 & 15,1 & 5,2 & 0 & 6,5 & 0 & 7,1 & 0 & 5,0 & 13,4 \\
\hline 4 & 3,7 & 2,0 & 5,7 & 0 & 4,3 & 0 & 3,3 & 0 & 6,0 & 0 \\
\hline 5 & 3,0 & 4,8 & 7,7 & 0 & 6,8 & 0 & 6,4 & 0 & 4,5 & 0 \\
\hline 6 & 5,0 & 5,4 & 8,1 & 0 & 6,1 & 0 & 4,4 & 8,5 & 6,4 & 0 \\
\hline 7 & 4,0 & 1,3 & 5,1 & 0 & 6,6 & 0 & 4,2 & 0 & 4,8 & 37,4 \\
\hline 8 & 4,2 & 0 & 5,9 & 0 & 6,9 & 0 & 2,4 & 0 & ttu & 14,8 \\
\hline 9 & 3,2 & 0 & 5,1 & 0 & 8,1 & 0 & 6,5 & 0 & 1,6 & 1,6 \\
\hline 10 & 3,6 & 0 & 5,8 & 0 & 6,3 & 0 & 4,7 & 0 & 4,0 & 0 \\
\hline 11 & 5,1 & 5,9 & 5,0 & 0 & 9,3 & 0 & 5,1 & 6,3 & 4,3 & 0 \\
\hline 12 & 2,2 & 4,6 & 6,4 & 0 & 6,8 & 0 & 4,8 & 0 & 3,1 & 0 \\
\hline 13 & 2,9 & 11,4 & 6,3 & 0 & 7,1 & 0 & ttu & 29,5 & $\mathrm{ttu}$ & 42,3 \\
\hline 14 & ttu & 10,5 & 6,9 & 0 & 4,2 & 1,5 & 5,8 & 0 & 3,2 & 5,0 \\
\hline 15 & ttu & 62,9 & 7,4 & 0 & 6,3 & 0 & 4,0 & 0,4 & ttu & 54,8 \\
\hline 16 & 4,2 & 0 & 6,0 & 0 & 4,3 & 0 & 3,1 & 0 & 3,3 & 0 \\
\hline 17 & 4,6 & 3,5 & 5,2 & 0 & 5,4 & 0 & 4,2 & 2,0 & 4,4 & 1,5 \\
\hline 18 & 5,1 & 0 & 4,7 & 0 & 6,2 & 0 & 4,8 & 0 & 1,0 & 0 \\
\hline 19 & 8,0 & 33,8 & 4,3 & 0 & 2,5 & 0 & 6,4 & 0 & 6,0 & 35,2 \\
\hline 20 & 6,3 & 0 & 6,9 & 0 & 2,6 & 0 & 3,9 & 0 & 5,1 & 10,7 \\
\hline 21 & 6,0 & 0 & 7,2 & 0 & 3,5 & 6,1 & 3,4 & 1,1 & 4,0 & 12,0 \\
\hline 22 & 2,8 & 0 & 3,6 & 0 & 5,5 & 0 & 4,1 & 7,0 & ttu & 48,7 \\
\hline 23 & 5,2 & 0 & 5,2 & 0 & 6,5 & 0 & 7,6 & 34,1 & 2,7 & 7,8 \\
\hline 24 & 5,1 & 0 & 8,4 & 0 & 4,0 & 0 & 5,1 & 0 & ttu & 58,3 \\
\hline 25 & $\mathrm{ttu}$ & 60,0 & 6,3 & 0 & 5,2 & 0 & 3,3 & 2,5 & 7,2 & 26,2 \\
\hline 26 & 4,8 & 0 & 7,1 & 0 & 5,8 & 23,4 & 3,4 & 0 & 5,9 & 15,0 \\
\hline 27 & 5,1 & 0 & 5,7 & 0 & 6,1 & 5,7 & 3,5 & 6,8 & 0,5 & 0 \\
\hline 28 & 4,2 & 0 & 6,8 & 0 & 7,3 & 0 & 5,7 & 0 & 2,7 & 0 \\
\hline 29 & 3,4 & 0 & 7,2 & 0 & 6,1 & 0 & 1,9 & 0 & 5,5 & 0 \\
\hline 30 & 4,6 & 0 & 6,0 & 0 & 7,3 & 0 & 1,9 & 3,7 & 3,1 & 3,5 \\
\hline 31 & 5,8 & 0 & & & 4,5 & 0 & & & 1,5 & 6,9 \\
\hline $\begin{array}{l}\text { Jumlah } \\
(\mathrm{mm})\end{array}$ & 130,6 & 221,2 & 182,4 & 0 & 180,7 & 36,7 & 134,6 & 101,9 & 101,1 & 405,5 \\
\hline $\begin{array}{c}\text { Rerata } \\
(\mathrm{mm} / \\
\text { hari) }\end{array}$ & 4,7 & 17,0 & 6,1 & 0 & 5,8 & 9,2 & 4,6 & 9,3 & 3,9 & 21,3 \\
\hline $\mathrm{HH}$ & & 13 & & 0 & & 4 & & 11 & & 19 \\
\hline
\end{tabular}

Sumber: Stasiun Politeknik Negeri Lampung (2014)

terdapat keuntungan sebesar 18, 19, dan 30\% apabila jagung dan kacang tanah ditanam secara tumpangsari dibanding monokultur. Pada lahan tumpangsari jagung dan kacang tanah dengan dosis $150 \mathrm{~kg}$ urea/ha untuk jagung nilai LER menunjukkan angka 1 yang berarti jagung dan kacang tanah memiliki hasil yang sama baik ditanam secara tumpangsari maupun monokultur. Pada lahan tumpangsari jagung dan kacang tanah dengan dosis 0, 50, dan $100 \mathrm{~kg}$ urea/ha untuk jagung nilai LER masingmasing 0,$79 ; 0,83$; dan 0,96 yang berarti tumpangsari 
jagung dan kacang tanah tidak menguntungkan. Hasil penelitian ini sejalan dengan hasil penelitian Nurmas (2011) yang menunjukkan bahwa walaupun bobot pipilan kering jagung pada pola tanam monokultur lebih baik dibanding pada pola tanam tumpangsari tapi tanaman jagung yang ditanam dengan pola tanam tumpangsari dengan kacang tanah baik dengan penanaman serentak maupun penundaan saat tanam jagung satu dan dua minggu menguntungkan dengan nilai LER masingmasing 1,$27 ; 1,39$; dan 1,37 .

\section{KESIMPULAN}

Berdasarkan hasil penelitian yang telah dilakukan, maka diperoleh kesimpulan bahwa penerapan tumpangsari jagung dan kacang tanah tidak menunjukkan efisiensi pemupukan urea secara agronomis karena peningkatan bobot pipilan kering jagung hanya sebesar $0,004 \mathrm{t} / \mathrm{ha}(4 \mathrm{~kg} / \mathrm{ha})$ setiap peningkatan dosis $1 \mathrm{~kg}$ urea/ha, pada pemberian pupuk sampai $300 \mathrm{~kg}$ urea/ha belum didapat dosis yang optimum. Efisiensi penggunaan lahan ditunjukkan oleh lahan tumpangsari jagung dan kacang tanah dengan dosis 200, 250, dan $300 \mathrm{~kg}$ urea/ha untuk jagung dengan nilai LER masing-masing 1,$18 ; 1,19 ;$ dan 1,30 .

\section{DAFTAR PUSTAKA}

Ahmad, Z., H. A. M. Mezori, dan M. M. S. Duhoky. 2008. Effect of intercropping systems and nitrogen fertilizer on yield, yield component of corn (Zea mays L.) and peanut (Arachis hypogaea L.). Jurnal Dohuk Univ. 11(1): 206214.

Arma, M. J., U. Fermin, dan L. Sabaruddin. 2013. Pertumbuhan dan produksi jagung (Zea mays L.) dan kacang tanah (Arachis hypogaea L.) melalui pemberian nutrisi organik dan waktu tanam dalam sistem tumpangsari. Jurnal Agroteknos. 3(1): 1-7.

Buhaira. 2007. Respons kacang tanah (Arachis hypogaea L.) dan jagung (Zea mays L.) terhadap beberapa pengaturan tanam jagung pada sistem tanam tumpangsari. Jurnal Agronomi. 11(1): 41-46.

Bustamam, T. 2004. Pengaruh posisi daun jagung pada batang terhadap pengisian dan mutu benih. Jurnal Stigma. 12 (2): 205-208.
Drechsel, P., P. Heffer, H. Magen, R. Mikkelsen, dan D. Wichelns. 2015. Managing Water and Fertilizer for Sustainable Agricultural Intensification. Penerbit International Fertilizer Industry Association (IFA), International Water Management Institute (IWMI), International Plant Nutrition Institute (IPNI), dan International Potash Institute (IPI): Paris, Perancis. $14 \mathrm{hlm}$.

Ezward, C. 2010. Uji pola tanam antara varietas jagung dengan varietas kedelai dan pengaruh efisiensi dosis imbangan $N, P$, dan $K$ terhadap pertumbuhan dan produksi jagung (Zea mays L.) dan kedelai (Glycine max L.). Tesis. Program Pascasarjana. Universitas Islam Riau. Riau. 109 hlm.

Hardjowigeno, S. 1987. Ilmu Tanah. PT. Melton Putra. Jakarta.

Hikmawati, M. 2014. Pengaruh varietas dan penggunaan dosis pupuk terhadap produksi jagung (Zea mays L.). Jurnal Media Soerjo. 14(1): 70-84.

Nurmas, A. 2011. Kajian waktu tanam dan kerapatan tanaman jagung sistem tumpangsari dengan kacang tanah terhadap nilai LER dan indeks kompetisi. Jurnal AGRIPLUS. 21(1): 61-67.

Pasau, P., P. Yudono, dan A. Syukur. 2008. Pergeseran komposisi gulma pada perbedaan proporsi populasi jagung dan kacang tanah dalam tumpangsari pada Regosol Sleman. Jurnal Ilmu Pertanian. 16(2): 60-78.

Pilbeam, C. J., M. Wood, dan P. G. Mugane. 1995. Nitrogen use in maize-grain legume cropping systems in semi-arid kenya. Jurnal Biol Fertil Soils. 20: 57-62.

Prasetyo, E. I. Sukardjo, dan H. Pujiwati. 2009. Produktivitas lahan dan NKL pada tumpangsari jarak pagar dengan tanaman pangan. Jurnal Akta Agrosia. 12(1): 51-55.

Purwaningsih, S. 2009. Populasi bakteri rhizobium di tanah pada beberapa tanaman dari Pulau Buton, Kabupaten Muna, Propinsi Sulawesi Tenggara. Jurnal Tanah Tropika. 14(1): 65-70.

Rahim, Y., J. E. X. Rogi, dan S. D. Runtunuwu. 2015. Pendugaan defisit dan surplus air untuk pengembangan tanaman jagung (Zea mays L.) di Kabupaten Gorontalo dengan menggunakan model simulasi neraca air. Jurnal ASE. 11(1): 11-17. 
Rahni, N. M. 2012. Karakteristik pertumbuhan dan hasil jagung (Zea mays L.) pada ultisols yang diberi pupuk hayati dan pupuk hijau. Jurnal AGRIPLUS. 22(3): 162-169.

Sabaruddin, L., Y. Koesmaryono, H. Pawitan, dan H. M. H. B. Djoefrie. 2003. Tanggap fisiologis tanaman jagung dan kacang tanah dalam sistem tumpangsari di lahan beriklim kering. Jurnal Agromet. 17(1-2): 21-29.

Siregar, A. dan I. Marzuki. 2011. Efisiensi pemupukan urea terhadap serapan $N$ dan peningkatan produksi padi sawah (Oryza sativa L.). Jurnal Budidaya Pertanian. 7(2): 107-112.

Sutoro, N. Dewi, dan M. Setyowati. 2008. Hubungan sifat morfofisiologis tanaman dengan hasil kedelai. Jurnal Penelitian Pertanian Tanaman Pangan. 27(3): 185-190.

Yuliana, A. I., T. Sumarni, dan S. Fajriani. 2013. Upaya peningkatan hasil tanaman jagung (Zea mays L.) dengan pemupukan bokashi dan Crotalaria juncea L. Jurnal Produksi Tanaman. 1(1): 3646. 